\title{
Gastrointestinal Endoscopy in Patients Receiving Antithrombotic Therapy
}

\author{
Supriadi*, Titong Sugihartono ${ }^{* *}$ \\ ${ }^{*}$ Department of Internal Medicine, Faculty of Medicine, Universitas Airlangga/Dr Soetomo General \\ Hospital, Surabaya \\ ** Division of Gastroentero-hepatology, Department of Internal Medicine, Faculty \\ of Medicine, Universitas Airlangga/Dr Soetomo General Hospital, Surabaya
}

\section{Corresponding author:}

Titong Sugihartono. Division of Gastroentero-hepatology, Department of Internal Medicine, Dr Soetomo General Hospital.Jl. Mayjen Prof. Dr. Moestopo no. 6-8 Surabaya Indonesia. Phone/facsimile: +62-31-5501078 Email: titongsppd@gmail.com

\begin{abstract}
Gastrointestinal endoscopy is used as a diagnostic and therapeutic tool. Patients receiving antithrombotic agents are at higher risk for bleeding in this procedure. Regarding its thromboembolic versus bleeding risk, physicians should consider to adjust antithrombotic therapy in patients undergoing gastrointestinal endoscopy. Some important factors including the urgency of the procedure, bleeding risk from the procedure and antithrombotic itself, and the risk of thromboembolic events during endoscopy if antithrombotic is to be stopped need to be considered wisely. Based on recommendations of ASGE, ESGE, and BSG, endoscopic procedures were divided based on the level of emergency, namely elective and urgent. In elective endoscopy with high risk of bleeding and thromboembolism, antithrombotic therapy is given in the minimum duration required and then discontinued before the procedure. In elective endoscopy with low risk of bleeding and thromboembolism, antithrombotic can be continued as usual. In urgent endoscopy due to gastrointestinal bleeding, all antithrombotic should be discontinued. Antithrombotic can be restarted within 48 hours after the procedure if no bleeding is evident
\end{abstract}

Keywords: Gastrointestinal Endoscopy, antithrombotic, antiplatelet, anticoagulant, thromboembolism

\begin{abstract}
ABSTRAK
Endoskopi gastrointestinal saat ini digunakan sebagai alat diagnostik dan terapi. Pasien yang menerima antitrombotik berisiko mengalami perdarahan dalam prosedur ini. Risiko terjadinya tromboemboli dan perdarahan harus dipertimbangkan oleh dokter untuk penyesuaian terapi antitrombotik pada pasien yang menjalani endoskopi gastrointestinal. Beberapa faktor yang harus dipertimbangkan yaitu tingkat urgensi dari prosedur, risiko perdarahan dari prosedur endoskopi dan dari penggunaan antitrombotik itu sendiri, serta risiko terjadinya tromboemboli selama endoskopi jika antitrombotik akan dihentikan. Berdasarkan rekomendasi ASGE, ESGE, dan BSG, prosedur endoskopi dibagi berdasarkan tingkat kegawatdaruratannya yaitu elektif dan urgen. Pada endoskopi elektif dengan risiko tinggi perdarahan dan tromboemboli, terapi antitrombotik diberikan dalam durasi minimum yang diperlukan kemudian dihentikan sebelum prosedur dilakukan. Pada endoskopi elektif dengan risiko perdarahan dan tromboemboli yang rendah, antitrombotik dapat dilanjutkan seperti biasa. Pada endoskopi urgen karena perdarahan gastrointestinal, semua antitrombotik harus dihentikan. Antitrombotik dapat dimulai kembali dalam waktu 48 jam setelah prosedur jika tidak terjadi perdarahan.
\end{abstract}

Kata kunci: Endoskopi, antitrombotik, antiplatelet, antikoagulan, tromboemboli 


\section{INTRODUCTION}

Gastrointestinal endoscopy is used as a diagnostic and therapeutic tool. As a diagnostic procedure, it is used to take tissue samples (biopsy), while as a therapeutic procedure, it is used for foreign body extraction, hemostasis processes, varicose sclerotherapy and dilatation of the narrowing. The complications of endoscopy are bleeding, infection, perforation, aspiration, local pain, arrythmia, and dehydration due to the use of laxatives and enemas as preparation. ${ }^{1}$

Patients receiving antithrombotic agents are at higher risk for bleeding in this procedure. While its use has been known to reduce risk of thromboembolic events in patients with atrial fibrillation, acute coronary syndrome, deep vein thrombosis, and stroke, it is associated with $14.5 \%$ (antiplatelet) and 4-6\% (anticoagulant) risk of upper gastrointestinal bleeding. Deaths have been reported in $8-10 \%$ of patients receiving anticoagulant therapy due to gastrointestinal

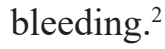

Regarding its thromboembolic versus bleeding risk, physicians should consider to adjust antithrombotic therapy in patients undergoing gastrointestinal endoscopy. Some important factors including the urgency of the procedure, bleeding risk from the procedure and antithrombotic itself, and the risk of thromboembolic events during endoscopy if antithrombotic is to be stopped need to be considered wisely. ${ }^{3,4}$ This article will review the management of gastrointestinal endoscopy in patients receiving antithrombotic therapy.

\section{Gastrointestinal endoscopy}

Gastrointestinal endoscopy can be divided according to reviewed organ, procedure indication, and its bleeding risk. From organ point of view, endoscopy has several types including esophagogastroduodenoscopy (esophagus, gaster, and duodenum), enteroscopy (small intestine), colonoscopy or sigmoidoscopy (large intestine), endoscopic retrograde cholangiopancreatography (biliary tract), rectoscopy (rectum), and anoscopy (anus). ${ }^{5}$

Conventional endoscopy views and takes tissue samples from biopsy. Several other can even evaluate blood flow and lesions in mucosal, submucosa or extraluminal lesions by the use of ultrasoundendoscope. While for therapeutic use, endoscopy is used for foreign body extraction, hemostasis process, drug injection, thermal coagulation, varicose sclerotherapy, laser debulking of the tumor, ablation therapy of a premalignant lesion, dilatation, placement of stents, reducing volvulus or intussusception, decompression of dilation, colon and feeding tube placement. ${ }^{1,6}$

European Society of Gastrointestinal Guidelines Endoscopy (ESGE), British Society of Gastrointestinal (BSG), American Society of Gastrointestinal Endoscopy (ASGE), Asian Pacific Association of Gastroenterology (APAGE), and Asian Pacific Society for Digestive Endoscopy (APSDE) classify endoscopic procedure as low and high risk based on its bleeding risk. ${ }^{4,7}$ Table 1 shows the endoscopic classification by its bleeding risk.

Table 1. Endoscopic procedure classification based on bleeding risk

\begin{tabular}{|c|c|c|c|}
\hline & ASGE & BSG-ESGE & APAGE-APSDE \\
\hline \multirow[t]{7}{*}{ Low risk procedure } & $\begin{array}{l}\text { Diagnostic including mucosal biopsy } \\
\text { ERCP with stenting or papillary balloon } \\
\text { dilation without sphincterotomy }\end{array}$ & $\begin{array}{l}\text { Diagnostic and biopsy procedure } \\
\text { Biliary or pancreatic stenting }\end{array}$ & $\begin{array}{l}\text { Diagnostic endoscopy with biopsy } \\
\text { ERCP with stenting }\end{array}$ \\
\hline & EUS without FNA & Diagnostic EUS & EUS without FNA \\
\hline & $\begin{array}{l}\text { Push enteroscopy and diagnostic } \\
\text { balloon-assisted enteroscopy }\end{array}$ & $\begin{array}{l}\text { Device-assisted enteroscopy without } \\
\text { polypectomy }\end{array}$ & $\begin{array}{l}\text { Diagnostic push or device assisted } \\
\text { enteroscopy }\end{array}$ \\
\hline & Capsule endoscopy & & Capsule endoscopy \\
\hline & Enteral stent deployment & & Esophageal, enteral, and colonic stenting \\
\hline & Argon plasma coagulation & & Argon plasma coagulation \\
\hline & Barrett's ablation & & \\
\hline \multirow[t]{11}{*}{ High risk procedure } & Polypectomy & Polypectomy & Polypectomy \\
\hline & ERCP with sphincterotomy & ERCP with sphincterotomy & ERCP with sphincterotomy \\
\hline & Ampullectomy & Ampullectomy & Ampullectomy \\
\hline & EMR/ESD & EMR/ESD & Therapy of varices \\
\hline & Endoscopic hemostasis & Therapy of varices & PEG/PEJ \\
\hline & PEG/PEJ & PEG & EUS with FNA \\
\hline & EUS with FNA & EUS with FNA & Dilatation of strictures \\
\hline & Pneumatic or bougi dilatation & Dilatation of strictures & \\
\hline & $\begin{array}{l}\text { Therapeutic ballon-assited } \\
\text { enteroscopy }\end{array}$ & Esophageal, enteral, or colonic stenting & \\
\hline & Tumor ablation & & \\
\hline & Cystgastrostomy & & \\
\hline
\end{tabular}




\section{Antithrombotic}

Antithrombotic consists of antiplatelet and anticoagulant agent. Antiplatelet is increasingly be used as thrombotic prevention not only in those with drug-eluting coronary stents, sometimes in form of dual antiplatelet therapy. ${ }^{10}$ While it reduces thromboembolic events, GI bleeding risk increased 1.8-fold with low dose aspirin and 7.4-fold with aspirin and clopidogrel dual therapy. ${ }^{11}$ Some of the commonly used antiplatelet will be discussed further.

Aspirin inhibits the synthesis of thromboxane A2 through irreversible acetylation of the enzyme cyclooxygenase. Thromboxane A2 is an arachidonic product that causes platelets to change shape, release granules and aggregate. After aspirin discontinuation, it takes 7-9 days to restore platelet function. ${ }^{4,12}$ Dipyridamole reversibly inhibits platelet aggregation. This drug is often used in combination with aspirin for stroke prevention. The exact mechanism is still controversial, but it is thought to inhibit cyclic nucleotide phosphodiesterase and adenosine uptake. Dipyridamole has a half-life of 12 hours and its effects is up to 2 days after discontinuation of the drug. ${ }^{4}$

Cilostazol is a more potent antiplatelet agent than ticlopidine or aspirin. It works by inhibiting the intracellular phosphodiesterase 3 enzyme, causing an increase in cyclic AMP, resulting in decreased platelet aggregation and vasodilation. It is usually stopped 2 days before procedure related to its half life. No dose adjustment is necessary in renal failure and hepatic impairment. ${ }^{4,13}$

The most commonly used antiplatelet after aspirin is thienopyridines. These drug binds to the P2Y12 receptor which prevents activation of the GPIIb/ IIIa receptor complex, thereby reducing platelet aggregation. Ticlopidine, the first widely available thienopyridine, has been largely replaced by newer second-generation drugs due to its haematological side effects (neutropenia, thrombotic trombocytopenic purpura, and hemolytic uremic syndrome). Clopidogrel is often used as a secondary prevention of MI or stroke and as primary management of peripheral vascular disease. Unlike clopidogrel, prasugrel doesn't requires multistage conversion to its active state, hence an increased risk of bleeding is more likely with prasugrel. On the other hand, ticagrelor is rapidly absorbed, does not require metabolic activation, and has a rapid antiplatelet effect. Therefore, it allows a shorter interval of discontinuation of 3 to 5 days to restore platelet function (versus 5 to 7 days with clopidogrel and prasugrel). ${ }^{4,14}$
Glycoprotein IIb/IIIa is a platelet surface integrin, receptors for fibrinogen and von Willebrand factor, which carry platelets to foreign surfaces and to inter platelets, thereby mediating platelet aggregation. Three drugs have been approved for use, namely tirofiban, abciximab and eptifibatide. The duration of action of these drugs is relatively short, with recovery of platelet aggregation within 6 to 12 hours after the drug is stopped. ${ }^{15}$

Vorapaxar is a competitive and selective inhibitor of PAR-1, the major receptor of thrombin on human platelets. It has been shown in clinical trials to reduce the risk of $\mathrm{MI}$, stroke, $\mathrm{CV}$ death, and revascularization procedures in patients with a history of previous MI or peripheral artery disease. However, it was associated with an increased risk of moderate or heavy bleeding of $4.2 \%$ versus $2.5 \%$ (placebo) and a $66 \%$ increased risk of bleeding overall. Vorapaxar significantly inhibited platelet aggregation that persisted for up to 4 weeks after discontinuation. ${ }^{4}$

Anticoagulant used is based on inhibition of anticoagulant factors. They are commonly used to reduce the risk of thromboembolic events in patients with atrial fibrillation, mechanical heart valves, deep venous thrombosis, and hypercoagulable conditions. Major GI bleeding as a complication of anticoagulant therapy occurs approximately $1-4 \%$ per year and a case fatality rate up to $10 \% .{ }^{10}$ Currently used anticoagulants include heparin, low molecular heparin (LMWH), Fondaparinux, VKAs, and DOACs.

Heparin binds to and activates the enzyme inhibitor antithrombin III (AT). The activated AT then inactivates thrombin, factor Xa and other proteases. Intravenous UFH has a half-life of 60 to 90 minutes, and the anticoagulant effect disappears 3 to 4 hours after discontinuation. ${ }^{4,16}$ Low molecular heparin (LMWH) inhibits the coagulation process through binding to AT, leading to a conformational change of AT which accelerates its inhibition of activated factor X (factor Xa). Enoxaparin and dalteparin were administered subcutaneously for the treatment of venous thromboembolism (VTE). This drug is also given at a reduced dose for the prevention of VTE in low-risk patients. This medicine should be last given 24 hours before the planned procedure. ${ }^{4}$

Fondaparinux is a specific factor $\mathrm{Xa}$ inhibitor. This drug is administered subcutaneously and in contrast to LMWH, Fondaparinux has a high affinity for antithrombin III, which inhibits factor Xa. The minimum recommended time for discontinuation of this drug before a high-risk procedure is 36 hours. ${ }^{4}$ 
Warfarin, a VKA agent, works by inhibiting clotting factors II, VII, IX, and X and proteins C and S. Warfarin is well absorbed after oral administration, but it takes 4-5 days to reach anticoagulant effect. Warfarin has a long half-life of about 40 hours and its activity is measured by the International Normalized Ratio (INR). The INR decreases to 1.5 in approximately $93 \%$ of patients within 5 days of discontinuation of therapy.,17

The newer agent, DOACs, works by as they directly inhibit either thrombin (dabigatran) or the activated coagulation factor X (rivaroxaban, apixaban, and edoxaban). There are some benefits over VKAs regarding its lower bleeding risk. Moreover, the rapid onset of anticoagulation (within 1-4 h) and the short halflife of DOACs (9-17 h) make initiation and interruption of therapy considerably easier than with VKAs. ${ }^{10}$

Rivaroxaban, apixaban, and edoxaban all have a relatively short time to achieve a therapeutic effect (e.g., 2-4 hours with rivaroxaban, 1-3 hours with apixaban), with half-lives ranging from 8 to 15 hours, and varying renal excretion (rivaroxaban $66 \%$ and apixaban 25\%). To minimize the risk of bleeding, these medications should be stopped for at least 2 half-lives before high-risk procedures, and the dosage of these drugs should be adjusted according to renal impairment. ${ }^{414}$ Dabigatran is mainly metabolized and excreted by the kidneys, achieving a maximum effect 1.25-3 hours after ingestion, with a half-life of 12 to 14 hours. The time to stop before the endoscopy procedure is determined by the patient's creatinine clearance because $80 \%$ of this drug is excreted via the kidneys. Meanwhile, Desirudin is a direct thrombin inhibitor approved for DVT prophylaxis following subcutaneous hip replacement surgery. The recommended discontinuation of this drug is 10 hours before a high-risk procedure. ${ }^{4}$

\section{Risk of Antithrombotic Discontinuation in Patients Undergoing Endoscopy}

The likelihood of thromboembolic events associated with antithrombotic discontinuation for endoscopic procedures depends on the indications for antithrombotic therapy and the characteristics of each patient. For example, in patients with non-valvular $\mathrm{AF}$, important factors that determine the risk of CVA (cerebrovascular accident) were included in the CHA2DS2-VASc index. ${ }^{4}$ Some conditions associated with thromboembolic risk with antithrombotic discontinuation are listed in Table 2.

\section{Role of Bridging Therapy}

To reduce the risk of a thromboembolic event, patients temporarily taking warfarin can be switched to a short-acting anticoagulant in the periendoscopic period. Evidence for the use of UFH and LMWH (enoxaparin) as a bridging therapy for endoscopic procedures in patients taking warfarin is limited. One study of 98 patients who underwent endoscopy (EGD and/or colonoscopy) with bridging therapy using bemiparin, a type of ultra-LMWH, found no thromboembolic events and only 2 bleeding episodes were not associated with endoscopy. ${ }^{4,18}$

\section{Urgent Endoscopy Procedure}

In patients with acute gastrointestinal bleeding, discontinuation of antithrombotic therapy is recommended to achieve hemostasis faster after considering its advantages and disadvantages. Endoscopic therapy is done in patients with serious GI bleeding and an INR $<2.5$, with 4-factor PCC, vitamin $\mathrm{K}$ and fresh frozen plasma can be given for life-threatening gastrointestinal bleeding in patients on warfarin anticoagulant therapy. Before stopping the antiplatelet in a patient suffers from gastrointestinal bleeding with a newly inserted intracoronary drug eluting stent $(<1$ year), within 30 days of insertion of an intracoronary metal stent, or within 90 days from the ACS incident, consultation to cardiologist is warranted. Those requiring anticoagulation should use UFH because of its relatively short half-life. , $^{3,4}$

Table 2. Conditions associated with thromboembolic risk with antithrombotic discontinuation 19

\begin{tabular}{|c|c|}
\hline Antiplatelet discontinuation & Anticoagulant discontinuation \\
\hline Two months after insertion of bare metal coronary artery stenting & History of cardiac and cerebral embolism \\
\hline Twelve months after drug eluting coronary artery stenting & Atrial fibrillation associated with valvular heart disease \\
\hline Two months after carotid artery revascularization (carotid stenting or endarterectomy) & $\begin{array}{l}\text { Atrial fibrillation without valvular heart disease but with a } \\
\text { high risk of having a stroke }\end{array}$ \\
\hline $\begin{array}{l}\text { Ischemic stroke or transient ischemic attack with more than } 50 \% \text { stenosis of the large } \\
\text { intracranial arteries }\end{array}$ & After mechanical mitral valve replacement \\
\hline History of recent ischemic stroke or transient ischemic attack & $\begin{array}{l}\text { History of thromboembolism after mechanical heart valve } \\
\text { replacement }\end{array}$ \\
\hline Peripheral artery disease (Fontaine $\geq$ grade 3 / rest pain) & Antiphospholipid antibody syndrome \\
\hline $\begin{array}{l}\text { Ultrasonography and magnetic resonance angiography of the head and neck showed a } \\
\text { high risk of thromboembolism if treatment was stopped }\end{array}$ & Venous thromboembolism \\
\hline
\end{tabular}




\section{Elective Endoscopy Procedure}

Patient undergoes elective procedure is divided based on bleeding and thrombotic risk. For those having high risk of bleeding and thromboembolic, it is recommended that endoscopy is delayed until administration of antithrombotic therapy is completed. Discontinuation of thienopyridines is suggested while low-dose aspirin (ASA) was continued. Patients who still need anticoagulants can use bridge therapy using short acting anticoagulants (LMWH and UFH). Patient receiving DOAC should be given the final dose 48 hours before the procedure. Information must be given regarding the increased risk of bleeding after the procedure compared to patients without anticoagulant treatment. ${ }^{3,4}$

Patients with high risk of bleeding but low risk of thromboembolism, antithrombotic (except aspirin) should be discontinued. On the other hand, those with low risk of bleeding but high risk of thromboembolic, antithrombotic should be continued, and for those receiving DOAC, last dose is given in the morning before procedure. Patients with low risk of bleeding and thromboembolic should continue their antithrombotic regimen. ${ }^{3,4}$

\section{Post Procedural Antithrombotic}

If antithrombotic is discontinued, it should be resumed within 48 hours after the procedure depending on the presence or absence of bleeding and thrombotic risk. If therapeutic dose of DOAC cannot be restarted within 12 to 24 hours after a high-risk endoscopic procedure, thromboprophylaxis, i.e., UFH (bridging therapy) should be considered to reduce the risk of thromboembolism. ${ }^{3,4}$

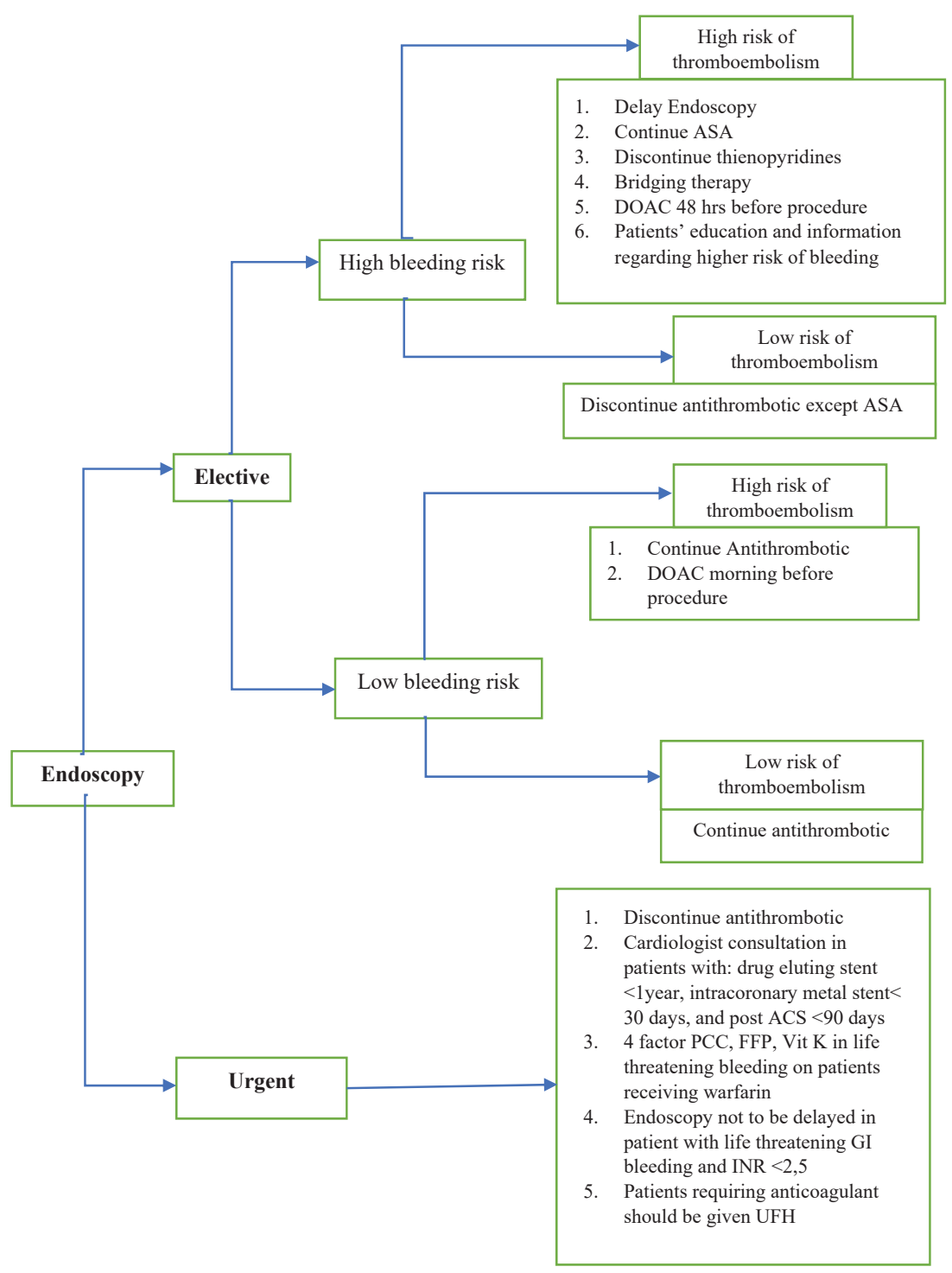

Figure 1. Gastrointestinal endoscopy management in patients receiving antithrombotic therapy $y^{3,4}$ 


\section{CONCLUSION}

Risk of bleeding and thromboembolism must be considered in patients receiving antithrombotic therapy requiring gastrointestinal endoscopy. Based on recommendations of ASGE, ESGE, and BSG in 2016, endoscopic procedures were divided based on the level of emergency, namely elective and urgent. In elective endoscopy with high risk of bleeding and thromboembolism, antithrombotic therapy is given in the minimum duration required and then discontinued before the procedure (aspirin can still be continued and anticoagulant bridging therapy can be considered). In elective endoscopy with low risk of bleeding and thromboembolism, antithrombotic can be continued as usual. In urgent endoscopy due to gastrointestinal bleeding, all antithrombotic should be discontinued while administration of 4 Factor PCC, Vitamin K, and FFP to patients taking warfarin must be considered. Antithrombotic can be restarted within 48 hours after the procedure if no bleeding is evident.

\section{REFERENCES}

1. Santacroce L. Gastrointestinal Endoscopy [serial online] [cited 2015 February 2]. Available from: http://www. emedicinehealth.com

2. Sengupta N, Feuerstein JD, Patwardhan VR, Tapper EB, Ketwaroo GA, Thaker AM, et al. The risks of thromboembolism vs. recurrent gastrointestinal bleeding after interruption of systemic anticoagulation in hospitalized inpatients with gastrointestinal bleeding: A prospective study. Am J Gastroenterol 2015;110:328-35.

3. Veitch AM, Vanbiervliet G, Gershlick AH. Endoscopy in patients on antiplatelet or anticoagulant therapy, including direct oral anticoagulants: British Society of Gastroenterology (BSG) and European Society of Gastrointestinal Endoscopy (ESGE) guidelines. journals Endosc Gut 2016;48:1-18.

4. Acosta RD, Abraham NS, Chandrasekhara V. The management of antithrombotic agents for patients undergoing GI endoscopy. Am Soc Gastrointest Endosc. 2016;83:1-16.

5. ASGE | Endoscopic Procedures [serial online]. [cited 2021 Mar 19]. Available from: https://www.asge.org/home/aboutasge/newsroom/media-backgrounders-detail/endoscopicprocedures

6. Ben-Menachem T, Decker GA, Early DS. Adverse events of upper GI endoscopy. Gastrointest Endosc 2012;76:707-18.

7. Chan FKL, Goh KL, Reddy N, Fujimoto K, Ho KY, Hokimoto $\mathrm{S}$, et al. Management of patients on antithrombotic agents undergoing emergency and elective endoscopy: Joint Asian Pacific Association of Gastroenterology (APAGE) and Asian Pacific Society for Digestive Endoscopy (APSDE) practice guidelines. Gut 2018;67:405-17.

8. Veitch AM, Vanbiervliet G, Gershlick AH, Boustiere C, Baglin TP, Smith LA, et al. Endoscopy in patients on antiplatelet or anticoagulant therapy, including Direct Oral anticoagulants: British Society of Gastroenterology (BSG) and European Society of Gastrointestinal endoscopy (ESGE) guidelines. Gut 2016;65:374-89.
9. Bestari MB, Laksono B. Current Guidelines on Antithrombotic Management in Patients Undergoing Gastrointestinal Endoscopy. Acta Med Indones 2019;51:86-92.

10. Zullo A, Hassan C, Radaelli F. Gastrointestinal endoscopy in patients on anticoagulant therapy and antiplatelet agents. Ann Gastroenterol 2017;30:7-14.

11. Strate LL, Gralnek IM. Management of patients with acute lower gastrointestinal bleeding. Am J Gastroenterol 2016;111:459-74.

12. James L. Zehnder M. Drugs Used in Disorders of Coagulation. In: Katzung BG, York N, San C, Athens F, Madrid L, City M, editors. Basic \& Clinical Pharmacology Fourteenth Edition a LANGE medical book [serial online]. Lange; 2018 [cited 2021 Mar 19]. p. 608-25. Available from: www.mhprofessional. com.

13. Richard Hall, Mazer CD. Antiplatelet Drugs: A Review of Their Pharmacology and Management in the Perioperative Period. Int Anesth Res Soc 2011;112:292-318.

14. Song LMWK, Topazian M. Gastrointestinal Endoscopy. In: Kasper DL, Fauci AS, editors. Harrison's Principles Of Internal Medicine $19^{\text {th }}$ Ed. New York: McGraw-Hill; 2015. p.1880-900.

15. Philip W Majerus, Tollefsen DM. Obat-Obat Antikoagulan, Trombolitik, dan Antiplatelet. In: Joel G Hardman, Limbird LE, eds. Goodman \& Gilman Dasar Farmakologi Terapi. Jakarta: EGC; 2012.p.1490-507.

16. Kester M, Karpa KD, Vrana KE. Elsevier's Integrated Review Pharmacology. second. Philadelphia: Elsevier Inc; 2012.

17. Neal MJ. Medical Pharmacology at a Glance. seventh. Oxford: Wiley-Blackwell; 2012.

18. Douketis JD, Spyropoulos AC, Spencer FA. Perioperative management of antithrombotic therapy. Chest 2012;141:32650 .

19. Kazuma Fujimoto, Mitsuhiro Fujishiro, Kato M. Guidelines for gastroenterological endoscopy in patients undergoing antithrombotic treatment. Dig Endosc 2014;26:1-14. 